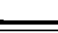

\title{
Zu meinem Artikel über Blasenerkrankungen in Nr. 24
} dieser Wochenschrift.

Von einem Groß-Berliner Kollegen moniert, entdecke ich, was ich nicht glauben mochte, mit peinlichemì Empfinden, daß ich bei der Aufzählung der bei Lithiasis wirkungsvollen Kurorte unseligerweise das in der Kladde aufgeführte Bad Wildungen in die Reinschrift des Manuskriptes nicht mit aufgenommen habe. $\mathrm{Da} B$ es mit an allererster Stelle rangiert, bedarf keines begründenden Wortes.

\footnotetext{
Fürbringer.
} 